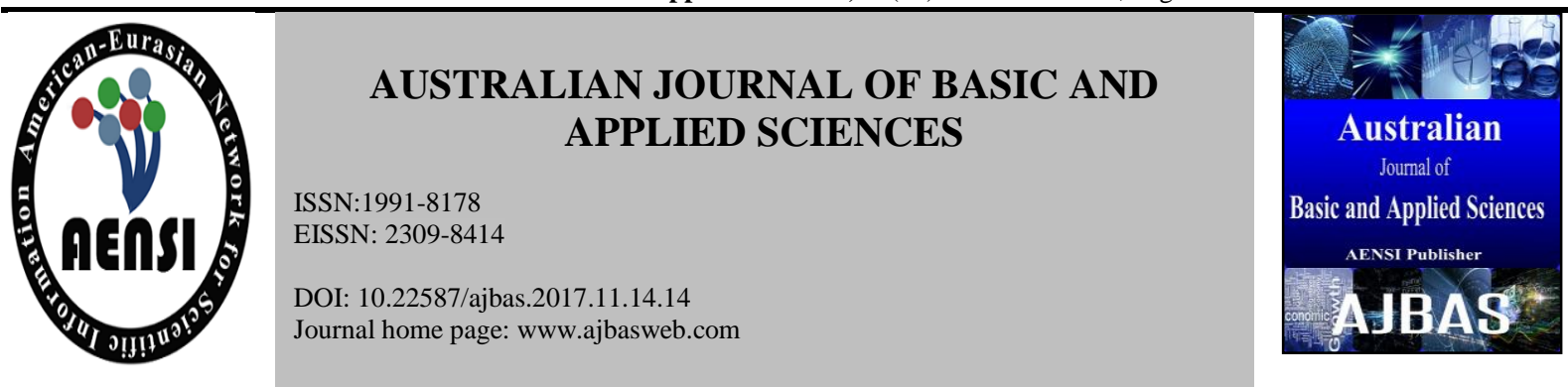

\title{
Using Fuzzy-Set Qualitative Comparative Analysis and Multiple Regression Analysis to Determine Tax Compliance Model for Vietnam
}

\author{
Nguyen Tien Thuc Ph.D \\ Lecturer, Trade \& Business Administration Faculty, Van Lang University, Ho Chi Minh City, Vietnam.
}

Address For Correspondence:

Nguyen Tien Thuc Ph.D, Van Lang University, Trade \& Business Administration Faculty, 233A Phan Van Tri , Binh Thanh District, Ho Chi Minh City, Vietnam.

E-mail: thucnguyentien@gmail.com

\section{A R T I CLE INF O}

Article history:

Received 12 October 2017

Accepted 22 November 2017

Available online 6 December 2017

\section{Keywords:}

fuzzy-set Qualitative Comparative Analysis; regression analysis; tax Compliance; configurational comparative approaches; calibrating fuzzy-sets.

\begin{abstract}
A B S T R A C T
Tax administration in a country has never been an easy and simple task, and a deep understanding of the factors affecting tax compliance is a vital task. We wonder if a single impacting factor may be useful or a compulsory combination of factors will be useful. The main purpose of this paper is to present the advantage of fsQCA in social sciences. It presents a non-popular approach in research, the combination of fuzzy-set Qualitative Comparative Analysis (fsQCA) and Multiple Regression Analysis (MRA) in hypothesis testing, for determining the Corporate Income Tax Compliance Model for Vietnam. This study is conducted by re-testing the Coporate Income Tax compliance model that used samples in Ho Chi Minh City only. The data used to re-test the hypotheses will come from five other provinces, sampling technique is simple random sampling. The first study of its kind, in order to examine to strengths and weaknesses of each methodological approach, it applies both fsQCA and MRA. The results shows that the statistically significant relationships between independent variables such as Business factor, Knowledge - Accounting Activities factor, Psychosocial factor, Tax Administration factor, Economic factor and dependent variable - Tax Compliance factor are identified; The results also shows that fsQCA leads to a more detailed understanding of the conditions under which the result occur than do MRA, and the using both of them to conduct the hypothesis test is better than using MRA only. By combining fuzzy-set Qualitative Comparative Analysis and Multiple Regression Analysis we can clearly and deeply understand the research problem more than do Multiple Regression Analysis only.
\end{abstract}

\section{INTRODUCTION}

In tax administration, one of problems that is not easily to know is what will make realistic predictions about what tax compliance will happen, and how they affect what happens in the future. We wonder if a single method or a combination of methods will be useful? The main purpose of this study is to answer this question. To answer this question, the theoretical model that has been successfully tested in Ho Chi Minh city-Vietnam will be re-tested in a geographical larger scope including five provinces of Vietnam. The theoretical model that will be re-tested in this study is presented in detail as follows:

Author (Nguyen Tien Thuc, 2015) built Corporate Income Tax Compliance Model in Ho Chi Minh City. First, this study used qualitative study to determine the initial research model, sampling technique is purposeful sampling. Second, this study used quantitative pilot study to test this initial research model by using factor analysis (EFA) and reliability analysis (Cronbach alpha). The result of this stage is the formal research model. Finally, the main study is conducted to test the hypotheses of the formal research model by using a quantitative main study that is conducted on a large-N (306 enterprises). In both quantitative studies, sampling technique is

Open Access Journal

Published BY AENSI Publication

(C) 2017 AENSI Publisher All rights reserved

This work is licensed under the Creative Commons Attribution International License (CC BY).

http://creativecommons.org/licenses/by/4.0/

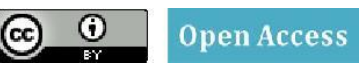

To Cite This Article: Nguyen Tien Thuc Ph.D., Using Fuzzy-Set Qualitative Comparative Analysis and Multiple Regression Analysis To Determine Tax Compliance Model For Vietnam. Aust. J. Basic \& Appl. Sci., 11(14): 102-122, 2017 
simple random sampling. Sampling frame is the list of enterprises came from the Tax Authorities database. The model had been determined as follows:

Table 1: Corporate Income Tax Compliance Model

\begin{tabular}{|c|c|c|}
\hline Competition on the market & \multirow{5}{*}{ Business Factor } & \multirow{23}{*}{ 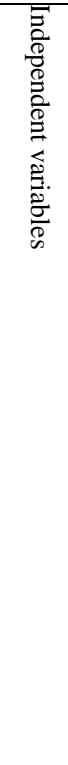 } \\
\hline Real ROE (Return On Equity) & & \\
\hline Risk Management & & \\
\hline Real revenue growth & & \\
\hline Capital Structure & & \\
\hline Tax Knowledge of owners & \multirow{3}{*}{$\begin{array}{l}\text { Knowledge-Accounting } \\
\text { activities Factor }\end{array}$} & \\
\hline Accounting Knowledge of owners & & \\
\hline The performance of the accounting department & & \\
\hline Social norms on tax compliance & \multirow{4}{*}{ Psychosocial Factor } & \\
\hline Public investment & & \\
\hline The tax spirit of the enterprise & & \\
\hline Fairness of the tax authorities & & \\
\hline Effective on tax law enforcement & \multirow{7}{*}{$\begin{array}{l}\text { Tax } \\
\text { Administration Factor }\end{array}$} & \\
\hline The probability of detecting irregularities enterprises & & \\
\hline The level of sanctions & & \\
\hline Stability of tax policy & & \\
\hline Transparency of tax policy & & \\
\hline Satisfaction on quality of tax service & & \\
\hline Unofficial costs & & \\
\hline Lending rates & \multirow{4}{*}{ Economic Factor } & \\
\hline Inflation & & \\
\hline Real tax rate & & \\
\hline Stability of the exchange rate & & \\
\hline Compliance with tax declaration regulations & \multirow{4}{*}{ Tax compliance Factor } & \multirow{4}{*}{ 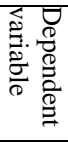 } \\
\hline Tax assessment & & \\
\hline Tax enforcement & & \\
\hline Compliance with tax payment regulations & & \\
\hline
\end{tabular}

The model includes six factors, they are Business factor, Knowledge-Accounting activities factor, Psychosocial factor, Tax administration factor, Economic factor and Tax compliance factor. The items in factors means:

(1) Competition on the market : competition in which every enterprise tries to get what other enterprises are seeking at the same time : sales, profit, and market share by offering the best practicable combination of price, quality, and service. If the competition on the market is low, the enterprise sales, profit, and market share will be high and therefore it is expected to be associated with a better degree of tax compliance of enterprises.

(2) Real ROE (Return On Equity) : Return on equity or return on capital is the ratio of net income of a enterprise during a year to its stockholders' equity during that year. It is a measure of profitability of stockholders' investments. It shows net income as percentage of shareholder equity. If the ROE is high, the enterprise cash flow will be good and therefore it is expected to be associated with a better degree of tax compliance of enterprise.

(3) Risk Management : In the world of business, risk management refers to the practice of identifying potential risks in advance, analyzing them and taking precautionary steps to reduce / remove the risks. If the effectiveness of the risk management task is good, the enterprise activities will be good and therefore it is expected to be associated with a better degree of tax compliance of enterprise.

(4) Real revenue growth : Real revenue growth indicates sales increases/decreases over real time. It is used to measure how fast a enterprise is expanding. More valuable than a snapshot of revenue, revenue growth helps enterprise identify trends in order to gauge revenue growth over real time. If the expected revenue growth is good, the growth prospects of the enterprise will be good and therefore it is expected to be associated with a better degree of tax compliance of enterprise.

(5) In theory, capital structure does not alter the value of a firm, so there is an incentive to use more debt and deduct interest expense to achieve tax savings. In reality, there is financial risk in taking on too much debt, so each enterprise must find a balanced structure. If the capital structure of enterprise is feasibly reasonable, the financial risk will reduce and therefore it is expected to be associated with a better degree of tax compliance of enterprise.

(6) Tax Knowledge : Tax knowledge is a familiarity, awareness or understanding of tax policies and tax law. If the owners have a good understanding of tax policies and tax law, they won't violate tax law and therefore it is expected to be associated with a better degree of tax compliance of enterprise.

(7) Accounting Knowledge : Accounting knowledge is a familiarity, awareness or understanding of accounting law. If the owners have a good understanding of accounting law, they will correctly calculate of tax liabilities and therefore it is expected to be associated with a better degree of tax compliance of enterprise. 
(8) The performance of the accounting department : The performance is an accomplishment of a given task measured against preset known standards of accuracy, completeness, cost, and speed. If the performance of the accounting department is high, they won't violate accounting law and tax law and therefore it is expected to be associated with a better degree of tax compliance of enterprise.

(9) Social norms on tax compliance : A norm is a group-held belief about how members should behave in a given context. Generally, social norms are described as informal understandings that govern individuals' behavior in society. If tax compliance behavior in the community is common, it is expected to be associated with a better degree of tax compliance of enterprise.

(10) Public investment : Public investment can be many things such as investment in machinery, buildings, facilities and computers. Operating expenditure on training, education and research is sometimes also regarded as investment. Physical investment is the most obvious, as it involves constructing new buildings, roads and facilities. This is the type of investment included in the public capital budgets, and it is also the focus area of the Government's strategic investment programme. If the enterprises ascertain that the public investment has the good results, they will have a better degree of tax compliance of enterprise.

(11) The tax spirit of the enterprise : Tax spirit means that the enterprise feel proud to pay taxes, they want to contribute to the community and therefore it is expected to be associated with a better degree of tax compliance of enterprise.

(12) Fairness of the tax authorities : if the tax authorities are not biased against any enterprise, they will be deemed as the fair tax authorities, this will contribute to tax compliance of enterprise and therefore it is expected to be associated with a better degree of tax compliance of enterprise.

(13) Effective on tax law enforcement : Effective on tax law enforcement is the capability of producing the desired results. When tax law enforcement is deemed effective, it means it has the intended or expected outcomes, or produces the deep, vivid impressions and therefore it is expected to be associated with a better degree of tax compliance of enterprise.

(14) The probability of detecting irregularities enterprises : In common usage, the word "probability" is used to mean the chance that a particular event (or set of events) will occur expressed on a linear scale from 0 (impossibility) to 1 (certainty), also expressed as a percentage between 0 and $100 \%$. When the probability of detecting irregularities enterprises is high, the enterprise will ponder the question of whether or not their violations will be detected and therefore it is expected to be associated with a better degree of tax compliance of enterprise.

(15) The level of sanctions : If the tax authorities realize that the enterprise have violated tax law then their response will depend on the gravity of the offence, based on Tax penalties \& sanctions. If the level of sanctions is high, the enterprise will thinking about the question of whether or not their offence will be detected and therefore it is expected to be associated with a better degree of tax compliance of enterprise.

(16) Stability of tax policy : Economic instability has risen in emerging economies after international economic integration. A more stable income tax policy could offer a stabilizing alternative. If the level of stability is high, the enterprise can easily comply the tax policy and therefore it is expected to be associated with a better degree of tax compliance of enterprise.

(17) Transparency of tax policy : The inexplicit tax policy can cause confusion in calculating or/and paying the tax obligations, the increased transparency around tax policy is seen as an essential part to help deal with these issues. Therefore it is expected to be associated with a better degree of tax compliance of enterprise.

(18) Satisfaction on quality of tax service : Organizations of all types and sizes have come to realize that their main focus must be to satisfy their customers, the tax authority also is not an exception. If the enterprise are not satisfied with quality of tax service, the level of tax compliance will be low. Therefore the satisfaction on quality of tax service is expected to be associated with a better degree of tax compliance of enterprise.

(19) Unofficial costs : The survey objects confirm that unofficial costs remain a heavy burden on many enterprises today. Bribery, party invitation, travel gifts and kickback for contracts approved are some popular forms of unofficial cost. They confirm that the removal of unofficial costs will make their tax compliance better.

(20) Lending rates : Lending rate is the bank rate that usually meets the short- and medium-term financing needs of the private sector. This rate is normally differentiated according to creditworthiness of borrowers and objectives of financing. The terms and conditions attached to these rates differ by country and economic condition. If the normal lending rate is low, the growth prospects of enterprise may be better and therefore it is expected to be associated with a better degree of tax compliance of enterprise.

(21) Inflation : Inflation is the percentage change in the value of the Wholesale Price Index (WPI) on a year to year basis. It effectively measures the change in the prices of a basket of goods and services in a year. When the general price level rises, each unit of currency buys fewer goods and services so the cost of enterprise will be increasing at an alarming rate. When the general price level rises in low, it is expected to be associated with a better degree of tax compliance of enterprise. 
(22) Real tax rate : The percentage at which an enterprise is taxed. The tax rate is the tax imposed by the government based on an enterprise's earnings. It directly impacts on the enterprise's income so if the tax rate is low, it is expected to be associated with a better degree of tax compliance of enterprise.

(23) Stability of the exchange rate : Exchange rates express the value of one country's currency in relation to the value of another country's currency. The rates play an important part in economics, affecting the balance of trade between nations and influencing the enterprise investment strategies. Stable exchange rates generally are viewed as favorable and therefore it is expected to be associated with a better degree of tax compliance of enterprise.

(24) Compliance with tax declaration regulations: The tax declaration regulations are related to the income information and tax obligations that an enterprise gives to the tax authorities once a year / a quarter. The tax declaration regulations always ask the enterprise for the honest, correct and timely declaration. The level of tax compliance is dependent on the level of compliance with tax declaration regulations.

(25) Tax assessment : Tax assessment is related to the tax obligations imposed by the tax authority based on the violations of an enterprise. The level of tax compliance is dependent on the level of tax assessment.

(26) Tax enforcement : Tax enforcement is related to the measures imposed by the tax authority in order to collect the tax debts of an enterprise. The level of tax compliance is dependent on the level of tax enforcement.

(27) Compliance with tax payment regulations : the tax payment regulations always ask the enterprise for the correct and timely payments. The level of tax compliance is dependent on the level of compliance with tax payment regulations.

In this model, variables have been measured with seven-level Likert scale that is ranging from Strongly disagree ("1") to Strongly agree ("7") and data required are cross data.

The model above had been successfully scientifically tested in Ho Chi Minh City.

Shaer Biabani and Adeleh Ramezani (2011) concluded that tax compliance is a complex behavior and it seems that there is not a general consensus in this respect. Various theoretical models have been developed in literature that according to this theoretical models, there are a wide range of effective factors on compliance behavior of taxpayers.

Alm, J. (1999) explored that there is no unique model that can explain the behavior of tax compliance.

Scandura, T., and Williams, E. (2000) inferred that social scientists have recognized that there isn't a perfect study that is viewed as the final answer to the research problems.

O'Leary Z (2004) confirmed that a study must be tested many times in many different research environments in order to find the truth.

Based on five reasons mentioned above, author chose the model mentioned above is the research model. The data used to re-test the model will come from five other provinces and both fuzzy-set Qualitative Comparative Analysis (fsQCA) and Multiple Regression Analysis (MRA) will be used, in order to examine to strengths and weaknesses of each methodological approach. In addition, the other purpose of this study is to comprehensively determine a coporate income tax compliance model for Vietnam.

Note that this theoretical model inherited from recent studies in the world and is in line with the research context in Vietnam. For these reasons and the research question above, it isn't necessary to discuss any recent references at all.

\section{Research Methodology and Hypotheses: Research Methodology:}

This study is started by using qualitative study. The research tool is in-depth interviews that can be used in most social science research situations. An in-depth interview is a tool of doing qualitative research. This is because an in-depth interview delves deeply into the attitudes of a single person instead of getting fairly superficial impressions of the ideas of a large number of people. In short, in-depth interviews are meant to discover answers to open-ended questions. In this study, an in-depth interview is associated with purposeful sampling that is selected based on the knowledge of a population and the purpose of the study. So that the surveyed objects are owners or/and general managers of enterprises. In order to identify Tax compliance concept. The first open question is that 'In your opinion what is Corporate Income Tax compliance? and why?'; the second open question is that 'Except for the mentioned factors, how about the following factors?' (Show them some other related items from the research model that they have not mentioned yet in order to confirm and/or examine their ideas and opinions. Sometimes, it is necessary to delve deeply discussion topic by using antipodal ideas). And factors impacting tax compliance is identified by the same way.

The quantitative pilot study is not done because the research model had been successfully scientifically tested in Ho Chi Minh City. So that, after the qualitative study has been done, the formal quantitative study will be done. The research tools used are reliability analysis (Cronbach alpha) and factor analysis (EFA). After factor analysis (EFA) has been done, the factor scores are used for two purposes: First, it is used for a multiple regression analysis (MRA), and statistical program is SPSS 11.5; Second, it is used for a fuzzy-set Qualitative Comparative Analysis (fsQCA), and and statistical program is fsQCA 2.5. 


\section{Research Hypotheses:}

Based on Nguyen Tien Thuc (2015) the original hypotheses in the Corporate Income Tax Compliance Model shown in Table 1, this study intend to test five hypotheses as follow:

H1 : A better degree of Business factor is expected to be associated with a better degree of tax compliance of enterprises.

$\mathrm{H} 2$ : A better degree of Knowledge-Accounting activities factor is expected to be associated with a better degree of tax compliance of enterprises.

H3 : A better degree of Psychosocial factor is expected to be associated with a better degree of tax compliance of enterprises.

H4 : A better degree of Tax administration factor is expected to be associated with a better degree of tax compliance of enterprises.

H5 : A better degree of Economic factor is expected to be associated with a better degree of tax compliance of enterprises.

\section{Results:}

The necessary samples are independently chosen. The first purposeful sample includes 20 Enterprises, the second purposeful sample includes other 7 Enterprises and both of them are used for qualitative study. Finally, the third random sample that including 326 Enterprises is used for quantitative study.

\section{a. Qualitative study:}

The qualitative study of independent variables is conducted within 20 Enterprises in five provinces by using purposeful sampling, the saturated point is 18 . In a similar way, the qualitative study of dependent variables is conducted within 7 Enterprises by using purposeful sampling, the saturated point is 5 . The provinces chosen by simple random sampling technique are Dong nai, Ba ria-Vung tau, Binh duong, Binh phuoc, Tay ninh. The results showed that the items in the research model do not change. So that five hypotheses above become the formal hypotheses in this study. Required data is collected in Feb 2016.

\section{b. Describing sample used for quantitative study:}

To test hypotheses, data was collected from a sample of 326 Enterprises in five provinces with simple random sampling technique. Enterprises were randomly selected from the Tax Authorities database. Required data is cross data collected in April 2016. The qualitative variables of this study includes 14 main qualitative variables that are explained as following:

(1) Age of enterprise : a period of an enterprise life, measured by years from inception.

(2) Form of ownership : Form of ownership includes private ownership, government ownership, foreign ownership and mixed ownership.

(3) Types of enterprise : Types of Enterprise includes limited liability companies, joint-stock companies, partnerships and private enterprises - referred collectively to as enterprises.

(4) Field operation : Field operation means that the particular kinds of the enterprise, the activity of providing goods and services involving financial, commercial and industrial aspects.

(5) Import and export operations: The enterprise may have import or/and export operation.

(6) Scale of capital : The scale of money, property, and other valuables which collectively represent the wealth of an enterprise. The scale of capital is measured by domestic currency.

(7) Number of employees: This is the size of the labor force, all the members of a particular enterprise who are able to work, viewed collectively.

(8) Time served of owner : a period of a working time, measured by years from starting mission.

(9) Concurrently position : A situation within an enterprise in which a person is responsible for two tasks both owner and director position.

(10) Education of owner : Education is commonly divided into stages such as preschool, primary school, secondary school and then college, university or apprenticeship.

(11) Gender of owner : It means that male or female.

(12) Age of owner : a period of a person life, measured by years from the date of birth.

(13) Tax procedures : A fixed, step-by-step sequence of activities or course of action (with definite start and end points) that must be followed in the same order to correctly perform the tax obligations. There are three forms of constant use: Self-realization, Outsourcing, Tax agent.

(14) And Province that is added in this study includes 5 provinces. The descriptions are as following 
Table 2: Sample descriptions 1

\begin{tabular}{|l|l|l|}
\hline Provinces & Frequency & Percent \\
\hline Dong Nai & 57 & 17.48 \\
\hline Binh Duong & 69 & 21.17 \\
\hline Binh Phuoc & 70 & 21.47 \\
\hline Tay Ninh & 66 & 20.25 \\
\hline Ba Ria-Vung Tau & 64 & 19.63 \\
\hline Total & 326 & 100 \\
\hline
\end{tabular}

Table 3: Sample descriptions 2

\begin{tabular}{|c|c|c|c|c|c|}
\hline Number of employees & Frequency & Percent & Field operation & Frequency & Percent \\
\hline Under 5 & 35 & 10.74 & Industry / Manufacturing & 73 & 22.39 \\
\hline Under 10 & 46 & 14.11 & Construction & 67 & 20.55 \\
\hline Under 50 & 36 & 11.04 & Services / Trade & 62 & 19.02 \\
\hline Under 200 & 32 & 9.82 & Agriculture/Forestry/Fisheries & 58 & 17.79 \\
\hline Under 300 & 40 & 12.27 & Mining & 66 & 20.25 \\
\hline Under 500 & 51 & 15.64 & Total & 326 & 100 \\
\hline Under 1000 & 40 & 12.27 & Import and export & Frequency & Percent \\
\hline Over 1000 & 46 & 14.11 & No & 167 & 51.23 \\
\hline Total & 326 & 100 & Yes & 159 & 48.77 \\
\hline Scale of capital & Frequency & Percent & Total & 326 & 100 \\
\hline Under 0.5 billion VND & 34 & 10.43 & Time served of owner & Frequency & Percent \\
\hline Under 1 billion VND & 34 & 10.43 & From 1 to under 2 years & 67 & 20.55 \\
\hline Under 5 billion VND & 43 & 13.19 & From 2 to under 3 years & 51 & 15.64 \\
\hline Under 10 billion VND & 40 & 12.27 & From 3 to under 4 years & 63 & 19.33 \\
\hline Under 50 billion VND & 49 & 15.03 & From 4 to under 5 years & 83 & 25.46 \\
\hline Under 200 billion VND & 50 & 15.34 & Over 5 years & 62 & 19.02 \\
\hline Under 500 billion VND & 41 & 12.58 & Total & 326 & 100 \\
\hline Over 500 billion VND & 35 & 10.74 & Education of owner & Frequency & Percent \\
\hline Total & 326 & 100 & Secondary School & 51 & 15.64 \\
\hline Age of Enterprise & Frequency & Percent & High School & 50 & 15.34 \\
\hline From 1 to under 3 years & 69 & 21.17 & 2 year college & 55 & 16.87 \\
\hline From 3 to under 5 years & 81 & 24.85 & 3 year college & 66 & 20.25 \\
\hline From 5 to under 7 years & 81 & 24.85 & University & 51 & 15.64 \\
\hline Over 7 years & 95 & 29.14 & Over University & 53 & 16.26 \\
\hline Total & 326 & 100 & Total & 326 & 100 \\
\hline Form of ownership & Frequency & Percent & Gender of owner & Frequency & Percent \\
\hline Private ownership & 77 & 23.62 & Male & 158 & 48.47 \\
\hline Government ownership & 80 & 24.54 & Female & 168 & 51.53 \\
\hline Foreign ownership & 89 & 27.30 & Total & 326 & 100 \\
\hline Mixed ownership & 80 & 24.54 & Age of owner & Frequency & Percent \\
\hline Total & 326 & 100 & $25-34$ & 79 & 24.23 \\
\hline Types of Enterprise & Frequency & Percent & $35-44$ & 61 & 18.71 \\
\hline Joint-stock companies & 144 & 44.17 & $45-54$ & 55 & 16.87 \\
\hline Limited liability company & 137 & 42.02 & $55-65$ & 71 & 21.78 \\
\hline Partnerships & 21 & 6.44 & Over 65 & 60 & 18.40 \\
\hline Private enterprises & 24 & 7.36 & Total & 326 & 100 \\
\hline Total & 326 & 100 & Tax procedures & Frequency & Percent \\
\hline
\end{tabular}




\begin{tabular}{|l|l|l|l|l|l|} 
Concurrently positions & Frequency & Percent & Self-realization & 105 & 32.21 \\
\hline Owner and Director & 157 & 48.16 & Outsourcing & 111 & 34.05 \\
\hline Owner or Director & 169 & 51.84 & Tax agent & 110 & 33.74 \\
\hline Total & 326 & 100 & Total & 326 & 100 \\
\hline
\end{tabular}

\section{c. Cronbach alpha and Exploratory Factor Analysis:}

In this study, variables have been measured with seven-level Likert scale that is ranging from Strongly disagree (" 1 ") to Strongly agree ("7'). For example, the surveyed objects will response for the statements : "The competition that your enterprise faces in the market is low"; "Real ROE is better than expected ROE"... They must to choose one of points on seven-level Likert scale. Required data to test the formal research model were obtained through questionnaires that used to interview enterprise's owners or/and general managers. The questionnaire includes 27 quantitative variables in the formal research model and 13 qualitative variables above.

Based on Kim J-O and Mueller CW (1978), Cronbach's alpha is a measure of internal consistency, that is how closely related a set of items are as a group. It is considered to be a measure of scale reliability. Note that a reliability coefficient of .70 or higher is considered "acceptable" in most social science research situations.. Exploratory factor analysis (EFA) is used to identify complex interrelationships among items and group items that are part of unified concepts. Factor analysis allows researchers to investigate concepts that are not easily measured directly by collapsing a large number of variables into a few interpretable underlying factors. The eigenvalue is a measure of how much of the variance of the observed variables explained by a factor. Any factor with an eigenvalue $\geq 1$ and factor loading $\geq 0.5$ will be accepted. The results of factor analysis and Cronbach's alpha is presented at Table 4 .

The Cronbach's alpha coefficients of the items are over 0.9 , that means the items have relatively high internal consistency.

Four dependent items were analyzed by using a Principal Component Analysis. The analysis yielded unique factor explaining $82.95 \%$ of the variance (Table 4 ) and the KMO coefficient is statistical significance. All items loaded clearly on this unique factor - Tax compliance Factor.

Twenty three independent items were analyzed by using a Principal Component Analysis with Varimax rotation (Table 4). The analysis yielded five factors explaining $96.87 \%$ of the variance in total and the KMO coefficien is statistical significance. All items loaded clearly on each factor. Factor 1 is Tax administration factor, factor 2 is Business factor, factor 3 is Psychosocial factor, factor 4 is Economic factor and factor 5 is Knowledge-Accounting activities factor. That means all the factors and their items in the research model is confirmed. The next step will be a multiple regression analysis.

Table 4: Cronbach alpha and EFA

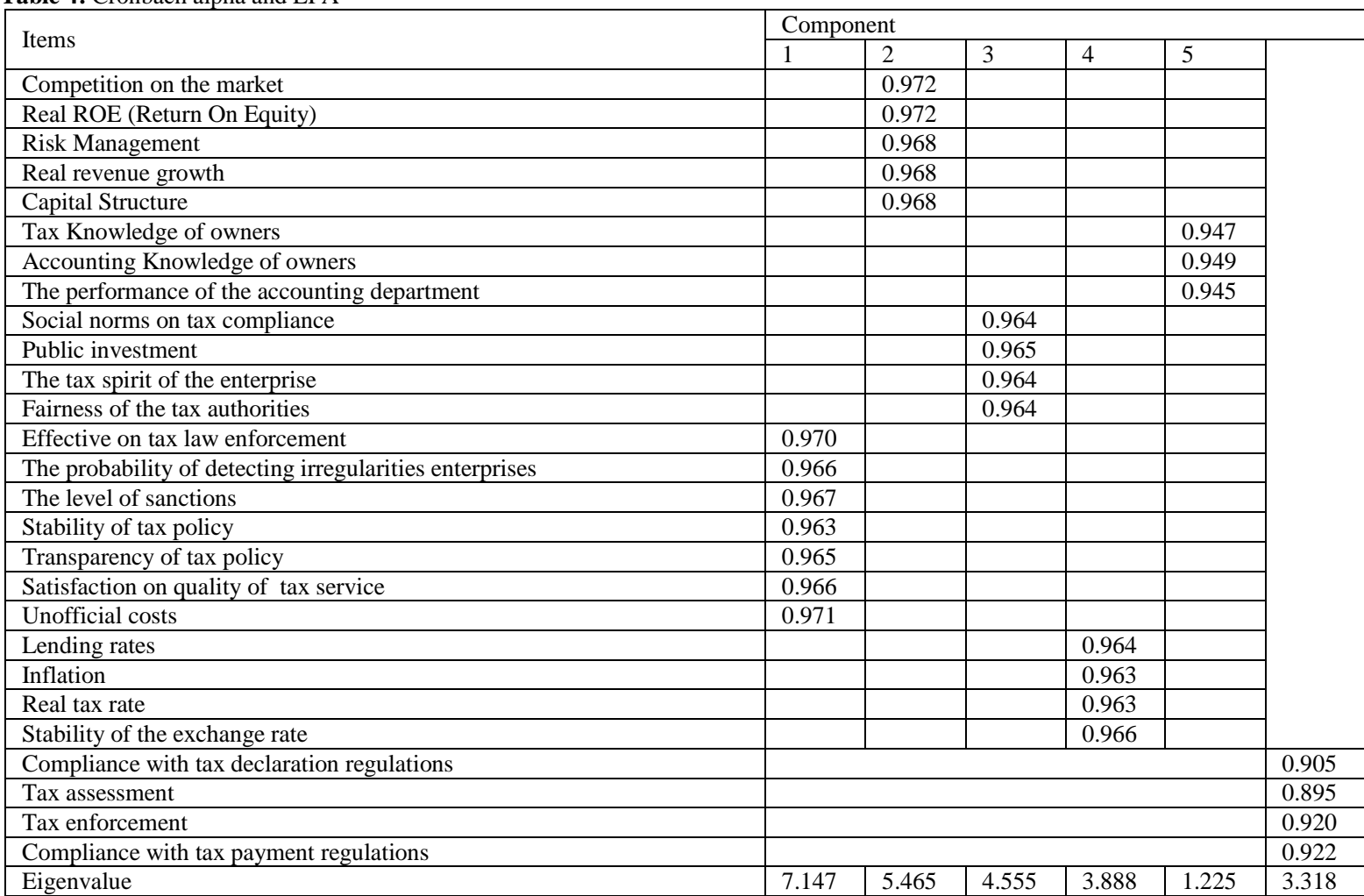




\begin{tabular}{|c|c|c|c|c|c|c|}
\hline$\%$ of Variance & 31.07 & 23.76 & 19.80 & 16.91 & 5.325 & 82.95 \\
\hline
\end{tabular}

Extraction Method: PCA. Rotation Method: Varimax with Kaiser Normalization.

\section{d. Regression analysis:}

Multiple regression analysis was used to test the hypotheses. The method used is Enter method in statistical program SPSS 11.5.

In Table 5, Sig. value is very small, so we safely reject the null hypothesis, $\mathrm{H}_{0}$ : the overall $\mathrm{R}$ Square coefficient is equal to zero, it indicates that the regression model constructed is fit in the collected data and useful.

In Table 6, Sig. value is very small, so we safely reject the null hypothesis, $\mathrm{H}_{0}$ : the overall regression coefficient is equal to zero, it also indicates that the regression model constructed is fit in the collected data and useful.

Table 5: Model Summary and ANOVA

\begin{tabular}{|c|c|c|c|c|c|}
\hline \multicolumn{6}{|c|}{ Model Summary } \\
\hline Model & $\mathrm{R}$ & R Square & $\begin{array}{l}\text { Adjusted } \\
\text { R Square }\end{array}$ & $\begin{array}{l}\text { Std. Error of } \\
\text { the Estimate }\end{array}$ & $\begin{array}{l}\text { Durbin- } \\
\text { Watson }\end{array}$ \\
\hline 1 & 0.842 & 0.709 & 0.705 & 0.393 & 2.105 \\
\hline \multicolumn{6}{|l|}{ ANOVA } \\
\hline & $\begin{array}{l}\text { Sum } \\
\text { Squares }\end{array}$ & df & $\begin{array}{l}\text { Mean } \\
\text { Square }\end{array}$ & $\mathrm{F}$ & Sig. \\
\hline Regression & 120.5282 & 5 & 24.1056 & 156.0171 & 0.00 \\
\hline Residual & 49.4421 & 320 & 0.1545 & & \\
\hline Total & 169.9703 & 325 & & & \\
\hline
\end{tabular}

Table 6: Coefficients

\begin{tabular}{|c|c|c|c|c|c|c|c|}
\hline & \multicolumn{2}{|c|}{$\begin{array}{l}\text { Unstandardized } \\
\text { Coefficients }\end{array}$} & \multirow{2}{*}{$\begin{array}{l}\text { Standardized } \\
\text { Coefficients } \\
\text { Beta } \\
\end{array}$} & \multirow[t]{2}{*}{$\mathrm{t}$} & \multirow[t]{2}{*}{ Sig. } & \multicolumn{2}{|c|}{$\begin{array}{l}\text { Collinearity } \\
\text { Statistics }\end{array}$} \\
\hline & $\mathrm{B}$ & Std. Error & & & & Tolerance & VIF \\
\hline (Constant) & -3.718 & 0.333 & & -11.15 & 0.00 & & \\
\hline Business Factor & 0.219 & 0.014 & 0.5715 & 16.175 & 0.00 & 0.72812 & 1.373 \\
\hline $\begin{array}{l}\text { Knowledge-Accounting activities } \\
\text { Factor }\end{array}$ & 0.320 & 0.015 & 0.7393 & 20.943 & 0.00 & 0.72947 & 1.371 \\
\hline Psychosocial Factor & 0.208 & 0.016 & 0.4551 & 13.093 & 0.00 & 0.75229 & 1.329 \\
\hline Tax Administration Factor & 0.318 & 0.020 & 0.5439 & 16.193 & 0.00 & 0.80572 & 1.241 \\
\hline Economic Factor & 0.358 & 0.015 & 0.8188 & 23.640 & 0.00 & 0.75766 & 1.320 \\
\hline
\end{tabular}

Standardization of the coefficient is usually done to answer the question of which of the independent variables have a greater effect on the dependent variable in a multiple regression analysis. Base on the results of regression analysis in Table 6, all research hypotheses are accepted and the regression equation with standardized coefficients is shown below:

Tax compliance $=0.818 *$ Ecomomic $+0.739 *$ Knowledge-Accounting activities $+0.571 *$ Business + $0.543 *$ Tax Administration $+0.455 *$ Psychosocial

And the regression equation with standardized coefficients of the previous study (Thuc, Nguyen Tien, 2015) also shows the same order of the net effects on the dependent variable of the independent variables :

Tax compliance $=0.547 *$ Ecomomic $+0.442 *$ Knowledge-Accounting activities $+0.321 *$ Business + $0.263 *$ Tax Administration $+0.213 *$ Psychosocial

Note that in both study, the Economic factor has the greatest net effect on the dependent variable and the other independent variables also have the net effects on the dependent variable in the same order. More specifically, the second is Knowledge-Accounting activities factor, the third is Business factor, the four is Tax Administration factor and the fifth is Psychosocial factor. 
That imply in case of limited resources the Government can base on the importance of the independent variables for determining tax policies and related policies. Note that the importance of the independent variables is based on the Standardized Coefficients as mentioned previously.

\section{e. To test regression assumptions:}

The assumptions of multiple regression that are identified as primary concern in the research include linearity, independence of errors, homoscedasticity, normality, and collinearity. This section will specifically test each of assumptions.

Residual plots showing the relationships between standardized residuals and the predicted values are very useful in detecting the violations in linearity assumption and homoscedasticity assumption. If there is a random scattering around the horizontal line, it will not violate in linearity assumption and homoscedasticity assumption. The Scatter Plot (Figure 1) is showing linear and isn't showing any curvilinear relationship between standardized residuals and predicted values, so the linearity assumption and homoscedasticity assumption will not be violated.

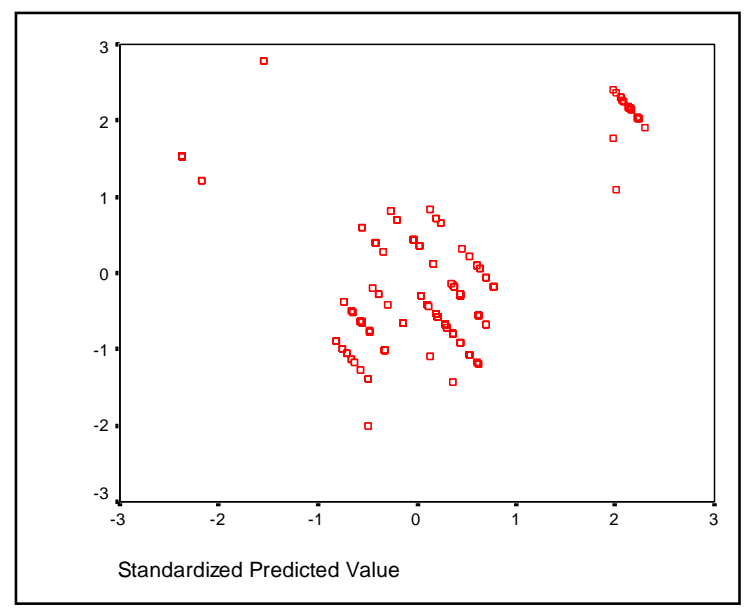

Fig. 1: Residual plots

In cases of cross data, the independence of errors assumption is always right, furthermore, the value of Durbin-Watson coefficient is ranging from 0 to 4 so that a value is around 2 indicating non-autocorrelation.

The assumption of multicollinearity refers to the assumption that the independent variables are uncorrelated. When a predictor variable has a strong linear association with other predictor variables, the Variance Inflation Factors (VIF) is large (over 10) and Tolerance coefficient is small (near 0), that is evidence of multicollinearity. Based on the value of VIF and Tolerance coefficient in this study, there isn't any multicollinearity phenomenon. (Table 6).

Based on Figure 2, we realize that variables approximately gain standard normal distribution $($ Mean $=0$; Stdev $=0.99$ ). Note that if $\mu=0$ and $\sigma=1$, the distribution is called the standard normal distribution or the unit normal distribution, and a random variable with that distribution is rarely exist in fact.

Based on Gujarati and Damonda (2003), because the above assumptions are not violated so the accuracies and inferences of this study are not affected by them.

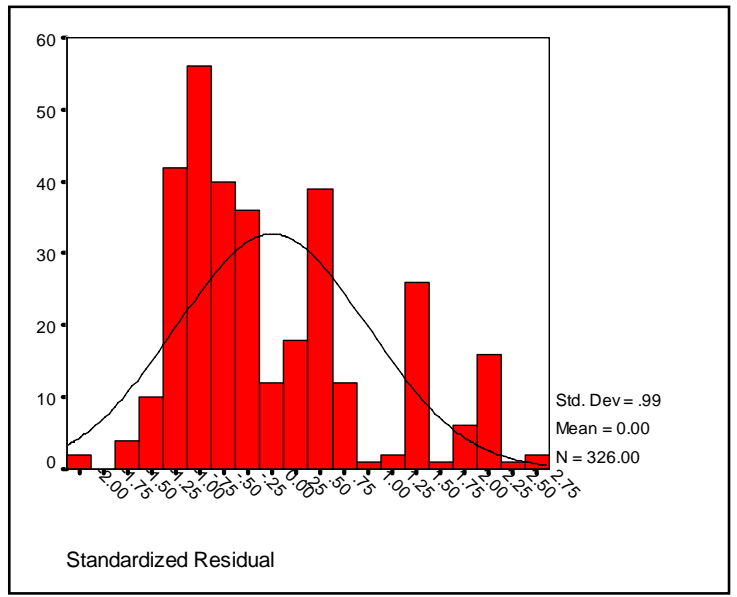

Fig. 2: Histogram with Normal Distribution 


\section{f. Analysis of Variance:}

The qualitative variables of this study includes 14 main qualitative variables as mentioned previously. This study used analysis of variance to test whether or not there is a difference in the the average of Tax compliance between each group of each qualitative variables. Both a parametric test (ANOVA) and a nonparametrict test (Kruskal - Wallis) was used to test following $14 \mathrm{H}_{0}$ hypotheses:

$\mathrm{H}_{0}$ : There isn't a difference in the the average of Tax compliance between each group of X (each of 14 qualitative variables)

The results confirmed that there is only a difference in the the average of Tax compliance between each group of Tax procedures. (Table 7 and Table 8). One of $\mathrm{H}_{0}$ hypotheses is rejected. This result differ from the previous study of Nguyen TienThuc (2015). In that study, all of the $13 \mathrm{H}_{0}$ hypotheses were accepted. That means the professional qualifications of Tax agents in five provinces as mentioned previously is not as good as Tax agents in Ho Chi Minh City. Note that the $14^{\text {th }} \mathrm{H}_{0}$ that is added in this study also is accepted.

$14^{\text {th }} \mathrm{H}_{0}$ : There isn't a difference in the the average of Tax compliance between each group of Province.

Table 7: One-way ANOVA

\begin{tabular}{|c|c|c|c|c|c|c|}
\hline \multicolumn{7}{|c|}{$\begin{array}{l}\text { Test of Homogeneity of Variances } \\
\text { Tax compliance Factor }\end{array}$} \\
\hline Levene Statistic & \multicolumn{2}{|l|}{ df1 } & \multicolumn{2}{|c|}{ df2 } & \multicolumn{2}{|l|}{ Sig. } \\
\hline 1.493 & 2 & & \multicolumn{2}{|c|}{323} & \multicolumn{2}{|l|}{0.226} \\
\hline \multicolumn{7}{|c|}{ ANOVA } \\
\hline \multicolumn{7}{|c|}{ Tax compliance Factor } \\
\hline & Sum of Squares & \multicolumn{2}{|l|}{$\mathrm{df}$} & Mean Square & $\mathrm{F}$ & Sig. \\
\hline Between Groups & 6.440 & \multicolumn{2}{|c|}{2} & 3.220 & \multirow[t]{2}{*}{6.360} & \multirow[t]{2}{*}{0.002} \\
\hline Within Groups & 163.531 & \multicolumn{2}{|c|}{323} & 0.506 & & \\
\hline Total & 169.970 & \multicolumn{2}{|c|}{325} & & & \\
\hline \multicolumn{7}{|c|}{ Post Hoc Test (Tax procedures group as a control) } \\
\hline \multicolumn{7}{|c|}{ Multiple Comparisons } \\
\hline \multicolumn{7}{|c|}{ Dependent Variable: Tax compliance Factor } \\
\hline \multicolumn{7}{|l|}{ Dunnett t (2-sided) ${ }^{\mathrm{a}}$} \\
\hline (I) Tax procedures & \multicolumn{2}{|l|}{ (J) Tax procedures } & \multicolumn{2}{|c|}{ Mean Difference (I-J) } & Std. Error & Sig. \\
\hline Self-realization & Tax agent & & $0.318^{*}$ & & 0.097 & 0.002 \\
\hline Outsourcing & Tax agent & & 0.038 & & 0.096 & 0.890 \\
\hline
\end{tabular}

Table 8: Kruskal-Wallis Test

\begin{tabular}{|l|l|l|l|}
\hline Ranks & Tax procedures & $\mathrm{N}$ & Mean Rank \\
\hline & Self-realization & 105 & 190.843 \\
\hline Tax compliance Factor & Outsourcing & 111 & 147.964 \\
\hline & Tax agent & 110 & 153.077 \\
\hline & Total & 326 & \\
\hline Test Statistics a,b & Tax compliance Factor \\
\hline \multicolumn{4}{|l|}{} \\
\hline Chi-Square & 13.783 \\
\hline df & 2 \\
\hline Asymp. Sig. & 0.001 \\
\hline a. Kruskal Wallis Test & \\
\hline b. Grouping Variable: Tax procedures & \\
\hline
\end{tabular}

\section{g. Fuzzy-set Qualitative Comparative Analysis (fsQCA):}

Based on Stockemer, D., (2013); Schneider, C.Q., \& Wagemann, C., (2012) and Zadeh, L. A., (1965), fsQCA can be understanded simply as follow:

It is possible to study 'INUS' conditions with QCA, 'INUS' conditions means insufficient but necessary parts of causal recipes which are themselves unnecessary but sufficient, by using QCA we can assess causation that is very complex. That means different combinations of causal conditions capable of generating the same results. This contrasts with the "net effects" focus prevailing in quantitative research. For example, we examine the following four models:
(1) $\mathrm{X} 1 \rightarrow \mathrm{Y}$
(2) $\mathrm{X} 1 * \mathrm{X} 2 \rightarrow \mathrm{Y}$
(3) $\mathrm{X} 1+\mathrm{X} 2 \rightarrow \mathrm{Y}(4) \mathrm{X} 1 * \mathrm{X} 2+\mathrm{X} 3 * \mathrm{X} 4 \rightarrow \mathrm{Y}$

In (1) X1 is necessary and sufficient; In (2) X1 (or X2) is necessary but not sufficient; In (3) X1 (or X2) is sufficient but not necessary; In (4) each of X1, X2, X3 and X4 is neither necessary nor sufficient, it is an 'INUS' condition. In QCA, this condition is called 'multiple conjunctural causation'. QCA's examination of cross-case patterns respects the diversity of cases and their heterogeneity with regard to their different causally relevant conditions and contexts by comparing cases as configurations. Causal complexity likes 'INUS' is pervasive but hard to tackle with conventional methods. 
Based on Zadeh, L. A., (1965) and Ragin (1987/2014), the fuzzy set theory can be used in a wide range of domains in which information is incomplete or imprecise, such as social sciences. Fuzzy sets are sets whose elements have various degrees of membership, that differ from classical set theory, an element either belongs or does not belong to the set. In fuzzy set, membership function valued in the real unit interval [0, 1]. Fuzzy sets are simultaneously qualitative and quantitative. Full membership and full non-membership are qualitative states. In between these two qualitative states are degrees of membership. Membership scores in sets can be scaled from 0 to 1 , with 0 indicating full exclusion and 1 indicating full inclusion. A score of .5 is the cross-over point. They allow precision.

Table 9: fsQCA and quantitative method

\begin{tabular}{|l|l|}
\hline fsQCA & Traditional quantitative methods \\
\hline Set & Variable \\
\hline Set relations & Statistical Correlation \\
\hline Calibration & Measurement \\
\hline Qualitative outcomes & Dependent variables \\
\hline Constructed populations & Given populations \\
\hline Truth table & Correlation matrix \\
\hline Configuration of conditions & Net effects \\
\hline Consistency; Raw Coverage; Unique Coverage. & R-square (MRA); Chi-square/df (SEM); Beta. \\
\hline
\end{tabular}

The fsQCA 2.5 software can be used to analyze calibration, truth tables, configuration of conditions, qualitative outcomes, consistency, raw coverage and unique coverage. To test the hypotheses, data collected by 7 point-scale Likert is calibrated and analyzed by fsQCA 2.5 software. We can see more at Ordanini, A., Parasuraman, A., and Rubera, G., (2014) and Woodside, A. G., (2013). The results of fsQCA is shown in Table 10 .

The last column of Table 10 shows the degree of consistency of each causal combination with the argument that it is a subset of the outcome Tax compliance, that means membership in the combination of conditions in this row is a subset of membership in the outcome. Consistency indicates the degree to which the sub-set relationship holds for sufficiency. Coverage gives an indication of the degree to which cases correspond to the (combination of) conditions. Table 10 shows combinations of INUS conditions:

Complex Solution and Intermediate Solution yields the following results:

Business * Knowledge-Accounting activities * Psychosocial * Economic + Business * KnowledgeAccounting activities $*$ Tax Administration * Economic $\rightarrow$ Tax compliance

Note that each of Business factor, Knowledge-Accounting activities factor, Psychosocial factor, Economic factor is neither necessary nor sufficient for Tax compliance, but their combination capable of generating sufficient for Tax compliance. That means Business * Knowledge-Accounting activities * Psychosocial * Economic is an INUS condition.

Similarly, each of Business factor, Knowledge-Accounting activities factor, Tax Administration factor, Economic factor is neither necessary nor sufficient for Tax compliance, but their combination capable of generating sufficient for Tax compliance. That means Business * Knowledge-Accounting activities * Tax Administration * Economic is also an INUS condition.

The parsimonious solution is as follows:

Business * Knowledge-Accounting activities * Economic $\rightarrow$ Tax compliance

Likewise, each of Business factor, Knowledge-Accounting activities factor, Economic factor is neither necessary nor sufficient for Tax compliance, but their combination capable of generating sufficient for Tax compliance. Also, their combination is an INUS condition.

All of hypotheses are accepted because all of conditions are necessary parts of causal recipes which are themselves unnecessary but sufficient for outcome. Note that in Boolean logic, logical AND (*) refers to intersection of sets and logical OR (+) to the combination of sets.

Table 10: Truth Table Analysis

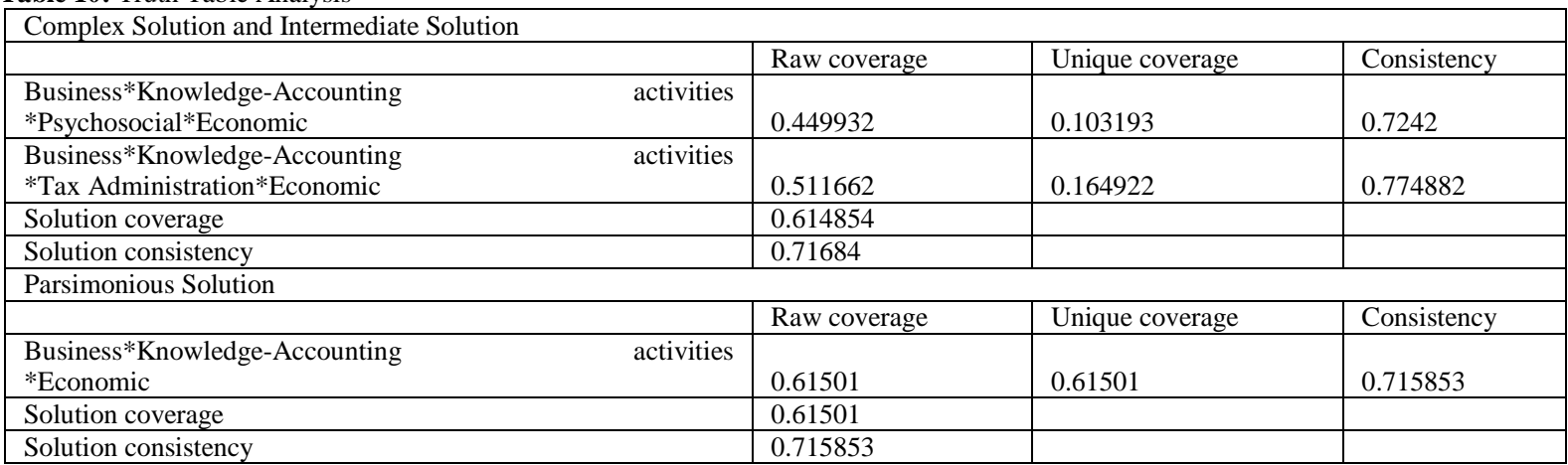




\section{Conclusions:}

In fsQCA, it is realized that Psychosocial factor and Tax Administration factor is interchangeable factors in the solutions to increase Tax compliance. Two combinations of a maximum of four factors and one combination of a minimum of three factors provide three solutions to increase Tax compliance in the context of there are five independent variables impacting on Tax compliance.

In the regression equation with standardized coefficients, as presented previously, each of Business factor, Knowledge-Accounting activities factor, Psychosocial factor, Tax Administration factor, Economic factor is sufficient cause for Tax compliance independently of each other. That means, (1) when Economic goes up by 1 standard deviation, Tax compliance goes up by 0.818 standard deviations; (2) when Knowledge-Accounting activities goes up by 1 standard deviation, Tax compliance goes up by 0.739 standard deviations; (3) when Busines goes up by 1 standard deviation, Tax compliance goes up by 0.571 standard deviations; (4) when Tax Administration goes up by 1 standard deviation, Tax compliance goes up by 0.543 standard deviations; and (5) when Psychosocial goes up by 1 standard deviation, Tax compliance goes up by 0.455 standard deviations.

This is a conventional view in quantitative research and it doesn't reflect causal complexity. We know net effects (standardized coefficients) but we don't know how many factors that must to be improved are enough for increasing Tax compliance. In the context of lack of resources in Tax management, the excess is wasted, on the contrary the shortage will be less effective.

Net effects indicate the degree to which the independent variables impact on dependent variable, the first three factors that are present at the regression equation also are present at parsimonious solution (fsQCA). So that in the context of lack of resources in Tax management, the combination of net effects-standardized coefficients (MRA) and parsimonious solution (fsQCA) will be lead to the best solution to increase Tax compliance:

A combination of Business, Knowledge-Accounting activities and Economic is a sufficient cause of Tax compliance.

And in the context of resources enough for Tax management, the solutions to increase Tax compliance will be one of two solutions:

A combination of Business, Knowledge-Accounting activities, Psychosocial and Economic is a sufficient cause of Tax compliance.

A combination of Business, Knowledge-Accounting activities, Tax Administration and Economic is a sufficient cause of Tax compliance.

This study determined the Corporate Income Tax Compliance Model for Vietnam by employing both fsQCA and MRA. The results also shows that fsQCA leads to a more detailed understanding of the conditions under which the result occur than do MRA, but the MRA leads to net effects, so that the using both of them to conduct the hypothesis test is better than using MRA only. The fsQCA is not the competitive method of MRA, it is the perfect complementary method of MRA.

The contributions of this study to knowledge are (1) we should be simultaneously employ both fsQCA and MRA in doing research in order to gain the top of deep understanding related our research questions and (2) the results of this study may be contributed a useful theoretical pattern to tax administration on the world.

\section{REFERENCES}

Alm, J., 1999. “Tax compliance and tax administration. In H. W. Bartley, Handbook on taxation”, New York: Marcel Deker.

Damonda and Gujarati, 2003. "Basic Econometrics, $4^{\text {th }}$ ed”, McGraw Hill.

Kim, J-O and C.W. Mueller, 1978. "Factor Analysis: Statistical Methods and Practical Issues", Beverly Hills CA: Sage.

Nguyen Tien Thuc, 2015. "Các yếu tố tác động đến sự tuân thủ thuế của doanh nghiệp trên địa bàn Thành phố Hồ Chí Minh”, Nhân lục khoa học xã hội, 03(22): 36-44.

Ordanini, A., A. Parasuraman and G. Rubera, 2014. "When the recipe is more important than the ingredients: A qualitative comparative analysis of service innovation configurations", Journal of Service Research, 17(2): 134-149.

O’Leary, Z., 2004. “The Essential Guide to Doing Research”, London: Sage.

Ragin, C.C., 1987/2014. "The Comparative Method: Moving Beyond Qualitative and Quantitative Strategies", Oakland, CA: University of California Press.

Scandura, T. and E. Williams, 2000. "Research methodology in organizational studies: Current practices and implications for future research". Academy of Management Journal, 43(6): 1248-1264.

Schneider, C.Q. and C. Wagemann, 2012. "Set-Theoretic Methods for the Social Sciences: A guide to Qualitative Comparative Analysis", New York, NY: Cambridge University Press. 
Shaer Biabani and Adeleh Ramezani, 2011. "An investigation of the factors effective on the compliance behavior of the tax payers in the VAT system: A case study of Qazvin tax affairs general department", African Journal of Business Management, 5(26): 10760-10768.

Stockemer, D., 2013. "Fuzzy set or fuzzy logic? Comparing the value of qualitative comparative analysis (fsQCA) versus regression analysis for the study of women's legislative representation", European Political Science, 12(1): 86-101.

Woodside, A.G., 2013. "Moving beyond multiple regression analysis to algorithms: Calling for adoption of a paradigm shift from symmetric to asymmetric thinking in data analysis and crafting theory", Journal of Business Research, 66(4): 463-472.

Zadeh, L.A., 1965. "Fuzzy sets", Information and Control, 8(3): 338-353. 